\title{
Membangun koneksi matematis siswa dalam pemecahan masalah verbal
}

\section{Nurfaidah Tasni ${ }^{1}$, Elly Susanti ${ }^{2}$}

\begin{abstract}
Abstrak: Penelitian ini mendeskripsikan proses membangun koneksi matematis dalam pemecahan masalah verbal atau soal cerita. Pada proses penyelesaian masalah verbal, diidentifikasi beberapa jenis koneksi yang dibangun siswa. Jenis soal dikembangkan berdasarkan karakteristik koneksi matematis menurut NCTM, yaitu koneksi antar topik matematika, koneksi dengan disiplin ilmu lain, dan koneksi dalam kehidupan sehari-hari. Pengumpulan data dilakukan melalui proses wawancara semi terstruktur terhadap 2 orang subjek yang dipilih dengan tehnik purposive sampling. Penelitian ini mengunkap ada tujuh jenis koneksi yang dibangun oleh siswa pada saat menyelesaikan masalah verbal, yaitu: koneksi pemahaman, koneksi jika maka, koneksi representasi yang setara, koneksi hirarki, koneksi perbandingan melalui bentuk umum, koneksi prosedur, dan koneksi justifikasi dan representasi.
\end{abstract}

Kata kunci: Koneksi Matematis; Pemecahan Masalah; Soal Verbal

\begin{abstract}
The current research aims to describe the process of developing mathematical connection in solving verbal or word mathematics problems. In solving problems, the mathematical connections developed by the subjects are identified. The mathematics problems refer to the characteristics of mathematical connections by NCTM, i.e. connections within mathematics topics, connection with other fileds, and connections with daily life. Data collection is conducted through students' work and semi-structure interview with two subjects. The subjects are selected through purposive sampling. This research reveals seven kinds of mathematical connections developed by the subjects in solving verbal mathematics problems, i.e. connection in understanding, if then connection, equal representation
\end{abstract}

\footnotetext{
${ }^{1}$ Universitas Negeri Malang, Malang, Indonesia, nurfaidatasni@rocketmail.com

2 Universitas Islam Negeri (UIN) Maulana Malik Ibrahim, Malang, Indonesia
} 
connection, hierarchy connection, proportion connection through general form, procedure connection, and justification and representation connection.

Keywords: Mathematical Connection; Problem Solving; Verbal Problems

\section{A. Pendahuluan}

Pemecahan masalah merupakan proses kompleks yang berhubungan dengan kegiatan kognitif, afektif dan psikomotorik (Serin \& Saygili, 2009). Selama proses pemecahan masalah siswa menafsirkan masalah, mengumpulkan informasi yang mereka butuhkan, menentukan solusi, menyajikan solusi dan mengevaluasi (Shamir, Zion, \& Levi, 2008). Hal ini mengindikasikan bahwa pemecahan masalah tidak hanya sebuah proses yang berakhir ketika jawaban telah ditemukan, melainkan mengevaluasi solusi merupakan proses ilmiah yang berkembang dari pemahaman masalah (Ozturk \& Guven, 2015). Menurut Hong dan Diamond (2012) strategi masalah ilmiah melibatkan kegiatan estimasi, pengamatan, analisis informasi dan pembentukan hasil. Strategi ini melibatkan proses pemecahan masalah yang secara bersamaan mengembangkan keterampilan siswa dalam berdiskusi dan berpikir tingkat tinggi (Hou, 2011).

Pemecahan masalah adalah proses ilmiah yang dilakukan seseorang untuk memahami masalah dalam rangka memutuskan informasi yang diperlukan untuk memperoleh solusi dan mengevaluasi kesesuain solusi dalam memecahkan masalah (Williams, 2003). Dalam proses pemecahan masalah, seseorang individu harus mampu menggabungkan operasi yang sesuai dan menerapkannya pada solusi (Bernardo, 1999). Pandangan ini didukung oleh Polya (1980) yang menjelaskan bahwa pemecahan masalah adalah menemukan makna yang dicari sampai akhirnya dapat dipahami dengan jelas. Memecahkan masalah berarti menemukan suatu cara menyelesaikan masalah, mencari jalan ke luar dari kesulitan, menemukan cara di sekitar rintangan, mencapai tujuan yang diinginkan, dengan alat yang sesuai. Dalam penelitian ini, proses pemecahan masalah berdasarkan langkah-langkah penyelesaian masalah yang dikemukakan oleh Polya 
yaitu memahami masalah, merencanakan pemecahan, menyelesaikan masalah sesuai rencana, dan memeriksa kembali hasil yang diperoleh.

Proses pemecahan masalah memerlukan membangun koneksi antara tahapan pemecahan masalah, sebagai upaya untuk menemukan solusi berdasarkan pengetahuan yang dimiliki (Schoenfeld, 1982). Hal ini mengindikasikan bahwa pengalaman siswa dalam memecahkan masalah, tentunya tidak dipisahkan dari adanya koneksi matematis. Melalui koneksi matematis siswa dapat mengembangkan pemahaman konseptual untuk menggunakan konsep-konsep matematika yang saling berhubungan dalam menyelesaikan masalah (Anthony \& Walshaw, 2009). Hal ini juga dipertegas oleh Rohendi dan Dulpaja (2013) yang mengemukakan bahwa kemampuan koneksi matematis sangat dibutuhkan oleh siswa, terutama untuk menyelesaikan masalah yang membutuhkan hubungan antara konsep-konsep matematika dengan konsep-konsep lain dalam matematika dan disiplin ilmu lain atau dalam kehidupan sehari-hari.

Membangun koneksi matematis adalah menghubungkan ide, konsep atau prosedur dalam matematika (Coxford, 1995). Ketika ide-ide matematika dihubungkan maka siswa bisa mengenali prinsip utama yang relevan dari beberapa pengetahuan (Jeniffer, Margaret, \& Mohr, 2011). The Oxford English Dictionary (2014) mendefinisikan koneksi sebagai hubungan, dimana seseorang, hal, atau ide terkait dengan sesuatu yang lain, sehingga koneksi matematis kemudian dinyatakan sebagai hubungan antara ide matematika yang terkait, atau berhubungan dengan ide matematika yang lainnya. Businskas (2008) dan Singletary (2012) memberikan defenisi yang sama untuk koneksi matematis yaitu hubungan antara dua ide matematika, dan antara satu kesatuan matematika dengan disiplin ilmu lainnya. Selanjutnya Skemp (1987) dan Zazkis (2000) mendefinisikan koneksi matematika sebagai representasi ide yang setara dalam matematika.

Di sisi lain, koneksi bisa dipandang sebagai konsekuensi yang alami dari teori konstruktivisme dalam domain matematika sebagai bentuk pemahaman konseptual dengan membangun jaringan terstruktur seperti jaring laba-laba dimana titik-titik atau simpul dapat dianggap sebagai potongan informasi yang diwakili, dan rangkaian diantara mereka sebagai koneksi atau hubungan (Hiebert \& Carpenter, 1992). Oleh karena itu, koneksi matematika dapat digambarkan sebagai komponen dari skema 
atau hubungan kelompok skema dalam jaringan mental. Skema adalah struktur memori yang berkembang dari pengalaman individu dan respon individu terhadap lingkungan (Marshall 1995).

Ketika siswa menghubungkan ide-ide matematika, pemahaman mereka lebih dalam dan lebih kekal, dan mereka akan melihat matematika sebagai suatu kesatuan yang utuh. Dari perspektif konstruktivis koneksi matematika seseorang dapat dianggap sebagai link atau jembatan dimana pengetahuan baru atau pengetahuan sebelumnya digunakan untuk membangun atau memperkuat pemahaman tentang hubungan antara ide matematika, konsep, alur, atau representasi dalam jaringan mental (NCTM, 2000). Berdasarkan penjelasan tentang defenisi dan tujuan dari koneksi, maka penelitian ini diarahkan untuk mengidentifikasi jenis koneksi yang dibangun siswa dalam proses pemecahan masalah verbal.

Salah satu upaya untuk melihat sejauh mana kemampuan pemecahan masalah yang dimiliki siswa adalah dengan memberikannya masalah dengan tingkat yang kompleks (Acosta, 2010). Masalah verbal dalam matematika merupakan jenis masalah matematika yang dirancang untuk membantu siswa menerapkan konsep-konsep matematika yang abstrak untuk situasi pada dunia nyata. Sehingga masalah verbal dapat dikategorikan sebagai masalah kompleks. Hal ini didukung oleh Hong dan Kim (2015) yang menyatakan bahwa memecahkan masalah dengan karakteritik masalah yang kompleks dan terbuka dapat meningkatkan pemikiran matematika tingkat tinggi dan dapat memperkuat kemampuan pemecahan masalah. Masalah verbal merupakan salah satu bagian sentral dari pembelajaran matematika, karena dalam proses penyelesaiannya mengkoneksikan penalaran dan pengetahuan matematika untuk kehidupan sehari-hari (Sepeng \& Webb, 2012).

Menyelesaikan soal cerita membantu siswa dalam mengembangkan keterampilan dan mengetahui kapan dan bagaimana menerapkan pengetahuan matematika dalam kehidupan sehari-hari (Sepeng \& Webb, 2012). Menurut Palm (2009) masalah verbal atau soal cerita mencakup tugas-tugas matematika murni yang dikemas pada situasi dunia nyata, yang mengharuskan siswa untuk menanggalkan pengemasan dan menyelesaikannya. Hal ini mengindikasikan bahwa masalah verbal dalam matematika merupakan jenis masalah yang dirancang untuk membantu 
siswa menerapkan konsep-konsep matematika yang abstrak untuk situasi pada dunia nyata.

Ada beberapa penelitian sebelumnya yang terkait dengan penggunaan koneksi matematis dalam pemecahan masalah. Stylianou (2013) memeriksa koneksi matematis dalam proses pemecahan masalah yang dilakukan siswa SMA. Pada penelitiannya ia menggambarkan adanya koneksi antara proses justifikasi dan representasi. Jaijan dan Loipha (2012) membuat koneksi matematis dengan transformasi pendekatan terbuka, yaitu melalui pemecahan masalah open ended. Selanjutnya Angeli dan Valanides (2012) melihat bagaimana koneksi keyakinan epistemologi dan penalaran siswa ketika berpikir tentang pemecahan masalah ill-structure. Masalah open ended atau ill-structure sering muncul dalam situasi dunia nyata. Namun, kesadaran siswa untuk menggunakan koneksi matematis dalam pemecahan masalah, khususnya memecahkan masalah aplikasi matematika yang biasanya disajikan dalam bentuk kalimat verbal masih rendah (Baki, Cathoglu, Costu, \& Brigin, 2009).

Berdasarkan fenomena tersebut, penelitian ini bertujuan untuk mengidentifikasi secara sfesifik koneksi yang dibangun oleh siswa dalam proses pemecahan masalah verbal. Sangat penting membangun koneksi matematis dalam proses pemecahan masalah, khususnya pemecahan masalah verbal. Dalam menyelesaikan masalah verbal, siswa tidak harus mengandalkan memori mereka saja. Dengan mengingat terlalu banyak konsep dan prosedur yang terisolasi ketika melakukan proses pemecahan masalah (Evitts, 2004). Untuk memenuhi tujuan tersebut siswa harus memiliki pengetahuan tentang jenis koneksi yang terjadi pada proses pemecahan masalah verbal. Dengan mengetahui jenis koneksi maka siswa akan terbiasa bekerja dengan membangun pengetahuan koneksi yang dimilikinya, dan secara langsung meningkatkan kemampuannya untuk memecahakan masalah verbal. Sehingga tulisan ini diarahkan untuk menggambarkan koneksi yang terjadi dalam proses pemecahan masalah verbal. Rumusan masalah dalam penelitian ini adalah bagaimana koneksi yang dibangun siswa dalam proses pemecahan masalah verbal?

\section{B. Metode Penelitian}

Pendekatan kualitatif digunakan dalam penelitian ini untuk mengidentifikasi koneksi yang terjadi dalam proses pemecahan masalah 
Verbal. Untuk menggambarkan secara sfesifik proses koneksi yang terjadi, dilakukan wawancara yang sifatnya semiterstruktur. Tujuannya untuk menemukan permasalahan dari fenomena yang diamati secara lebih terbuka (Esterberg, 2002). Dalam menyelidiki suatu fenomena, peneliti membuat suatu gambaran kompleks, menelaah kata-kata, laporan terinci dan pandangan responden serta melakukan studi pada situasi yang alami (Cresswell, 2015). Oleh karena itu, dalam rangka memperoleh gambaran tentang jenis koneksi yang terjadi dalam proses pemecahan masalah verbal, peneliti memberikan soal dalam bentuk verbal kepada siswa. Siswa diberikan waktu beberapa menit kemudian diberikan kesempatan untuk menyelesaikan soal sambil di wawancarai.

Subjek penelitian adalah siswa SMP Kelas VIIIA di Kabupaten Bulukumba Sulawesi Selatan yang telah mempelajari materi Sistem Persamaan Linear Dua Variabel (SPLDV). Purposive Sampling digunakan sebagai tehnik sampling yaitu dengan memilih individu dan tempat yang paling membantu peneliti dalam memahami fenomena yang akan diamati (Creswell, 2015). Oleh karena itu, dipilih 2 orang siswa yang dikategorikan memiliki kemampuan kognitif yang tinggi. Terpilihnya 2 orang siswa sebagai subjek penelitian, berdasarkan perolehan nilai tes awal tertinggi dan didukung dari rekomendasi guru kelas. Materi tes awal dikembangkan dari materi yang pernah dipelajari sebelumnya. Setelah dilakukan pemilihan subjek, selanjutnya dilakukan pemilihan soal-soal pada materi SPLDV yang memungkinkan memunculkan berbagai jenis koneksi dalam proses penyelesaiannya.

Jenis masalah verbal yang diberikan kepada subjek dikembangkan bedasarkan tiga karakteristik koneksi yang dijelaskan dalam NCTM, yaitu: koneksi antar topik matematika, koneksi dengan disiplin ilu lain, dan koneksi dalam kehidupan sehari-hari. Ketiga jenis soal tersebut adalah sebagai berikut:

1. Teguh memiliki sejumlah kelereng hijau dalam kantong $A$ dan kelereng hitam dalam kantong B. la memasukkan sepertiga kelereng hijau ke kantong $B$, sebaliknya setengah kelereng hitam dimasukkan ke kantong A. Jika dalam kantong A dan B masing-masing ada 14 dan 9 kelereng, maka banyak kelereng hijau adalah?

2. Ipul akan memberi sebuah kado ulang tahun untuk Tina, kado tersebut akan dimasukkan ke dalam sebuah kotak berbentuk balok 
yang panjangnya $60 \mathrm{~cm}$, lebar $20 \mathrm{~cm}$ dan tingginya $40 \mathrm{~cm}$. Agar nampak menarik, kotak kado itu akan dibungkus dengan kertas kado yang memiliki panjang $70 \mathrm{~cm}$ dan lebar $50 \mathrm{~cm}$. Berapa lembarkah kertas kado yang harus dibeli ipul agar tidak kurang untuk digunakan membungkus kado tersebut?

3. Seorang atlet berlari mengelilingi taman berbentuk belah ketupat sebanyak 50 kali. Jika panjang diagonal taman masing-masing $16 \mathrm{~m}$ dan $30 \mathrm{~m}$, jarak yang ditempuh atlet adalah?

\section{Temuan dan Pembahasan}

Pada soal nomor satu subjek menerapkan koneksi pemahaman. Koneksi pemahaman yaitu koneksi yang dibangun berdasarkan kemampuan subjek mengidentifikasi unsur-unsur yang diketahui dan ditanyakan dalam soal, untuk mengetahui konsep dan prosedur yang akan digunakan sebagai strategi penyelesaian. Hal ini teridentifikasi dari kemampuan subjek untuk mengkoneksikan setiap unsur-unsur yang diketahui dan ditanyakan dalam soal. Selanjutnya menyusun strategi penyelesaian dengan memisalkan unsur-unsur tersebut. Proses tersebut tergambar dalam penggalan wawancara dan Gambar 1 berikut ini.

$P \quad$ : Apa yang anda pahami setelah membaca soal nomor satu?

CA : Saya menuliskan dulu unsur-unsur yang diketahui dan ditanyakan dalam soal bu.

P : Seperti Apa itu?

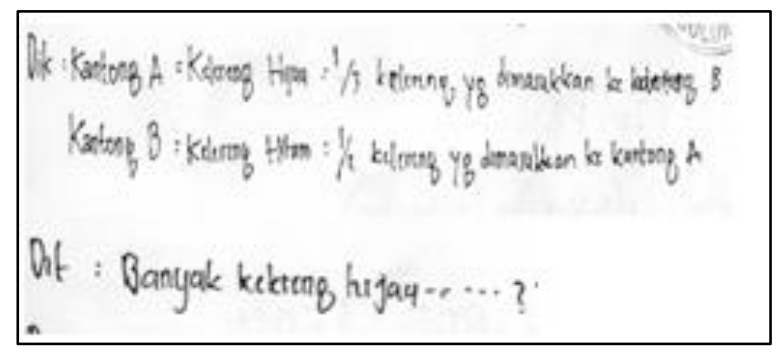

Gambar 1. Subjek mengidentifikasi unsur-unsur yang diketahui dan ditanyakan

Jenis koneksi lain yang muncul yaitu koneksi jika maka. Koneksi jika maka terkait erat dengan generalisasi tetapi tidak secara ekslusif yaitu koneksi yang terbentuk dari proses menverifikasi/membuktikan melalui 
pengamatan dan penalaran logis (Toulmin, 2008). Koneksi ini terjadi pada saat subjek menyelesaikan masalah dengan menggunakan analisis verbal secara langsung, berdasarkan kesimpulan yang diambil subjek dari potongan-potongan informasi yang diketahui sebelumnya. Potongan informasi tersebut dipandang sebagai premis. Dalam matematika, penalaran deduktif atau logika adalah jenis penalaran yang kesimpulannya adalah harus mencapai fakta-fakta yang diketahui sebelumnya (premis). Menurut Toulmin jika premisnya benar, kesimpulan harus benar. Proses tersebut tergambar dalam Gambar 2 berikut ini.

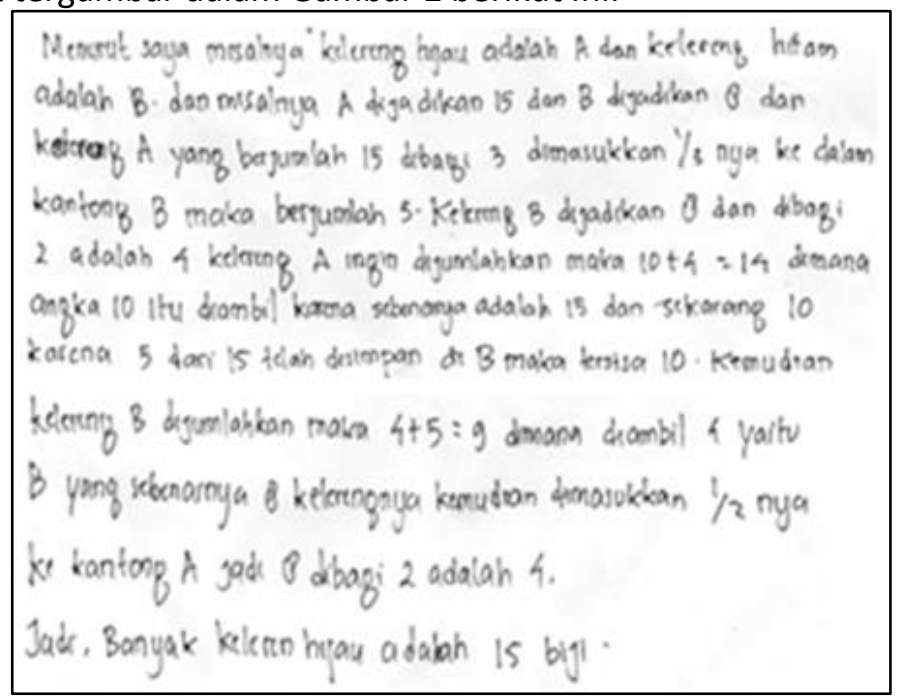

Gambar 2. Proses penyelesaian masalah yang dilakukan subjek

Jenis koneksi selanjutnya adalah representasi yang setara yang muncul pada tahap evaluasi. Representasi yang setara yaitu salah satu konsep yang direpresetasikan dengan cara yang berbeda tetapi dalam bentuk yang sama atau satu konsep bisa diwakili dengan simbol yang berbeda (Suominen, 2015). Hal ini diidentifikasi dari kemampuan subjek untuk membuktikan kebenaran jawaban yang diperoleh dengan menggunakan representasi yang berbeda yaitu dari representasi verbal ke representasi simbolik. Proses tersebut dapat diamati dalam penggalan wawancara berikut ini.

$P \quad$ : Apa yang kamu lakukan untuk membuktikan kebenaran jawaban yang kamu peroleh?

CA : hmmm......(Subjek terdiam sejenak). Saya bisa membuat model matematikanya dulu bu 
$P \quad$ : Lalu setelah itu apa yang kamu lakukan?

CA : Saya akan menyelesaikannya dengan metode eliminasi substitusi bu...

Pada soal kedua, subjek melakukan koneksi hirarki. Koneksi hirarki adalah salah satu konsep merupakan komponen dari konsep lain (Suominen, 2015). Karena salah satu konsep disertakan atau terkandung dalam konsep lain, hubungan hirarki ada diantara dua konsep tersebut. Hal ini dapat diidentifikasi pada saat subjek mampu menentukan konsep yang tepat, untuk digunakan dalam menyelesaikan masalah. Konsep tersebut adalah konsep balok yang mewakili luas permukan kado dan konsep persegi yang mewakili luas kertas. Selanjutnya perbandingan luas permukaan balok dan luas persegi dijadikan dasar untuk menentukan jumlah kertas yang dibutuhkan. Hal ini mengindikasikan subjek melakukan koneksi hirarki, yaitu salah satu konsep merupakan komponen dari konsep lain. Seperti yang kita ketahui persegi panjang adalah bagian dari balok. Proses tersebut dapat diamati dari penggalan wawancara berikut ini.

$P \quad$ : Selanjutnya, apa yang akan kamu lakukan untuk menyelesaikannya?

CA : hmmmm........ (Subjek terdiam dan memikirkan strategi penyelesaian). Saya akan menentukan luas permukaan kado keseluruhan yang berbentuk balok dan menentukan luas satu buah pembungkus yang berbentuk persegi panjang.

Pada penyelesaian soal ketiga, subjek menentukan panjang sisi taman dengan menkoneksikannya dengan konsep Pythagoras, namun terjadi kekeliruan pada saat subjek menentukan panjang diagonal dari belah ketupat. Tanpa menyadari kesalahannya, subjek melanjutkan pekerjaannya dengan menkoneksikan keliling belah ketupat yang diilustrasikan sebagai sebagai jarak tempuh atlet. Namun karena ada kesalahan saat menentukan panjang sisi taman maka jawaban yang diperoleh tidak tepat. Kesalahan yang dilakukannya diketahui pada saat subjek melakukan tahap evaluasi. Subjek selanjutnya memperbaiki kesalahan yang dilakukannya. Proses tersebut dapat diamati dari penggalan wawancara berikut. 
$P \quad$ : Apakah anda yakin dengan kebenaran jawaban anda?

CA : Hmmm.....saya perhatikan dulu bu ... (Subjek melihat kembali proses penyelesaian soal yang telah dikerjakan). Sepertinya ada kesalahan pada panjang diagonalnya bu.

$P \quad$ : lalu seperti apa anda akan memperbaikinya?

CA : Saya akan membagi dua panjang diagonal yang diketahui bu

$P \quad$ : Mengapa anda berpikir seperti itu?

CA : Karena saya membutuhkan panjang sisi keliling belah ketupat, oleh karena itu saya akan menggunakan teorema pythagoras.

..... (Subjek memberikan penjelasan sambil memperbaiki langkah penyelesaian yang keliru)

Selanjutnya berdasarkan pengamatan terhadap proses penyelesaian pada soal nomor tiga, subjek melakukan koneksi perbandingan melalui bentuk-bentuk umum. Koneksi perbandingan melalui bentuk umum yaitu dua konsep dari beberapa fitur yang sama, yang memungkinkan terjadinya perbandingan melalui kemiripan, kesamaan, atau perbedaan dari konsep tersebut (Suominen, 2015). Koneksi ini diidentifikasi dari pemikiran subjek yang mengilustrasikan sebuah taman dengan bidang belah ketupat. Proses tersebut dapat diamati dalam gambar 3 berikut ini.

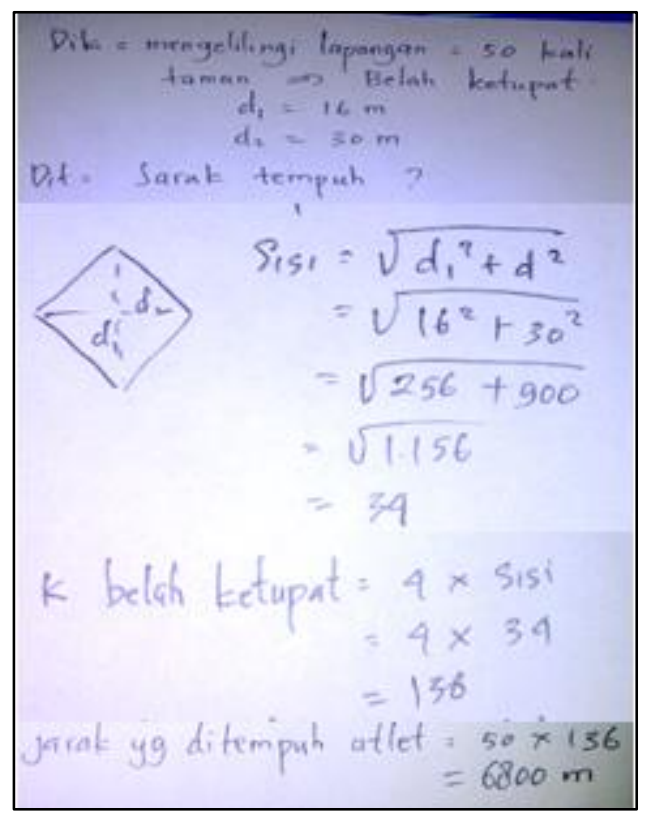

Gambar 3. Proses penyelesaian soal ketiga 
Berdasarkan Gambar 3 dapat diidentifikasi bahwa selain koneksi hirarki subjek juga melakukan koneksi prosedural. Koneksi Prosesdural adalah salah satu konsep dapat digunakan untuk menemukan konsep lain (Suominen, 2015). Konsep tersebut dapat menjadi prosedur atau metode yang digunakan untuk mengkoneksikan suatu konsep ketika bekerja dengan konsep lain. Hal ini tampak dari konsep Pythagoras yang digunakan subjek untuk menentukan panjang sisi keliling dari belah ketupat. Secara umum koneksi justifikasi dan representasi terjadi pada langkah penyelesaian ketiga soal. Proses ini dapat dilihat dari kemampuan subjek untuk mengevaluasi kebenaran jawaban yang diperoleh dengan konsep dan prosedur yang digunakan.

\section{Simpulan}

Dari hasil penelitian, dapat disimpulkan jenis koneksi yang terjadi dalam proses pemecahan masalah verbal sebagai berikut:

1. Koneksi pemahaman, yaitu koneksi yang dibangun berdasarkan kemampuan subjek mengidentifikasi unsur-unsur yang diketahui dan ditanyakan dalam soal, untuk mengetahui konsep dan prosedur yang akan digunakan sebagai strategi penyelesaian.

2. Koneksi jika maka, yaitu koneksi yang dibangun oleh subjek pada saat menyelesaikan masalah dengan menggunakan analisis verbal secara langsung, berdasarkan kesimpulan dari potongan informasi. Potongan informasi dipandang sebagai suatu premis dari penarikan kesimpulan.

3. Koneksi representasi yang setara, yaitu koneksi yang dibangun berdasarkan konsep yang direpresentasikan dengan cara dan bentuk yang berbeda tetapi memiliki nilai yang sama. Dalam penelitian ini menunjukkan kesetaraan dari representasi verbal ke simbolik.

4. Koneksi hirarki, yaitu koneksi yang dibangun berdasarkan hubungan hirarki antara dua konsep atau salah satu konsep merupakan komponen dari konsep lain.

5. Koneksi perbandingan melalui bentuk umum, yaitu koneksi yang dibangun berdasarkan perbandingan bentuk dua konsep yang memiliki kemiripan. Dalam penelitian ditunjukkan melalui 
penggunaan konsep belah ketupat untuk menentukan keliling taman yang menyerupai belah ketupat.

6. Koneksi prosedural, yaitu koneksi yang dibangun berdasarkan penggunaan suatu konsep pada saat bekerja dengan metode atau prosedur tertentu.

7. Koneksi justifikasi dan representasi, yaitu koneksi yang dibangun pada saat subjek mengevaluasi kebenaran jawaban yang diperoleh, dengan konsep dan prosedur yang digunakan.

\section{Daftar Pustaka}

Acosta, E. (2010). Making mathematics word problem reliable measures of students mathematics abilities. Journal of Mathematics Education, 3(1), 15-26.

Angeli, C., \& Valanides, N. (2012). Epistemological beliefs and ill-structured problem-solving in SOLO and paired contexts. Educational Technology \& Society, 15 (1), 2-14.

Anthony, G., \& Walshaw, M. (2009). Characteristics of effective teaching of mathematics: a view from the west. Journal of Mathematics Education, 2(2), $147-164$.

Baki, A., Cathoglu, H., Costu, S., \& Brigin, O. (2009). Conceptions of high school students about mathematical connections to the real-life. Procedia Social and Behavioral Sciences, 1, 1402-1407.

Bernardo, A. B. (1999). Overcoming obstacles in understanding and solving word problems in mathematics. Educational Psychology: An International Journal of Experimental Educational Psychology, 19(2), 144-163.

Businskas, A. M. (2008). Conversations about connections: How secondary mathematics teachers conceptualize and contend with mathematical connections. Unpublished PhD thesis, Simon Fraser University, Barnaby, Canada.

Coxford, A. F. (1995). The case for connections. Dalam P. A. House \& A. F. Coxford (Eds). Connecting Mathematics Across The Curriculum (pp $3-12$ ). Reston VA: NCTM.

Creswell. (2015). Planning, conducting, and evaluating quantitave and qualitative research. Universty of Nebraska-Lincoln; Pearson.

Evitts, T. A. (2004). Investigating the mathematical connections that preservice teachers use and develop while solving problems from reform curricula. Unpublished doctoral dissertation, Pennsylvania State University. 
Hiebert, J \& Carpenter, T. (1992). Learning and teaching with understanding. Dalam D. Grouws (Ed), Handbook of Research on Mathematics Teaching and Learning (pp. 65 -97). New York: Macmillan.

Hong, S. Y \& Diamond, K. E. (2012). Two approaches to teaching young children sciences concepts, vocabulary, and scientific problem solving skills. Early Childhood Research Quarterly, 27(2), 295-305. Doi: 10.1016/j.ecresq.2011.09.006.

Hong, Y. J \& Kim. M. (2015). Mathematical abstraction in the solving of illstructured problem by elementary school students in Korea. Eurasia Journal of Mathematics, Science \& Technology Education, 2016, 12(2), 267 $-281$.

Hou, H. T. (2011). A case study of online instructional collaborative discussion activities for problem-solving using situated scenarios: An examination of content and behavior cluster analysis. Computers \& Education, 56(3), 712719. Doi: 10.1016/j.compedu.2010.10.013.

Jeniffer, A., Margaret, J., \& Mohr, S. (2011). Exploring mathematical connection of prospective middle - grades teachers through card - sorting tasks. Math Ed Res J, 23, 297 - 319. Doi: 10.1007/s13394-011-0017-0.

Marshall, S. (1995). Schemas in problem solving. Cambridge: Cambridge University Press.

NCTM. (2000). Principles and standards for school mathematics. Reston, VA: Author.

Ozturk, T \& Guven, B. (2015). Evaluating students' beliefs in problem solving process: A case study. Eurasia Journal of Mathematics, Science \& Technology Education, 12(2), 411-429.

Palm, T. (2009). Theory of authentic task situations. Dalam L. Verschaffel, B. Greer, W. Van Dooren, \& S. Mukhopadhyay (Eds.), Words And Worlds: Modelling Verbal Descriptions of Situations (pp.3-19). Rotterdam: Sense Publishers.

Polya, G. (1973). How to solve it. Princeton, USA: Princeton University Press.

Serin, O., Serin, N. B., \& Saygilı G. (2009). The effect of educational technologies and material supported science and technology teaching on the problem solving skills of 5 th grade primary school student. Procedia Social and Behavioral Sciences, 1(1), 665-670. Doi: 10.1016/j.sbspro.2009.01.116.

Shamir, A., Zion, M., \& Levi, O. S. (2008). Peer tutoring, metacognitive processes and multimedia problem-based learning: the effect of mediation training on critical thinking. Journal of Science Education and Technology, 17(4), 384-398. Doi: 10.1007/s10956-008-9108-4.

Sepeng, P., \& Webb, P. (2012). Exploring mathematical discussion in word problem-solving. Pythagoras, 33(1), Art. \#60. Doi: 10.4102/pythagoras. v33i1.60. 
Singletary, L. M. (2012). Mathematical connections made in practice: An examination of teachers' beliefs and practices. Unpublished dissertation, University of Georgia, Athens, GA.

Skemp, R. R. (1987). The psychology of learning mathematics. Harmondsworth, England: Penguin.

Stylianou, D. (2013). An examination of connections in mathematical processes in students' problem solving: connections between representing and justifying. Journal of Education and Learning, 2 (2).

Suominen, L.A. (2015). Abstract algebra and secondary school mathematics: identifying and classifying mathematical connections. Unpublished PhD thesis, The University of Georgia.

Toulmin, S. E. (2008). The layout of arguments. Dalam J. E. Adler \& L. J. Rips (Eds.), Reasoning: Studies of human inference and its foundations. (pp. 652-677). New York: Cambridge University Press.

Williams, K. M. (2003). Writing about the problem solving process to improve problem solving performance. The Mathematics Teacher, 96(3), 185 - 187.

Zazkis, R. (2000). Factors, devisors and multiples: Exploring the web of student's connections. CBMS Issues in Mathematics Education, 8, $210-$ 238. 